\title{
Artículos
}

\section{Effects of Social Network and Destination on Earnings and Economic Integration of Female Mexican Migrants}

\section{María Teresa Gastón*}

\section{Received: April, 2013 / Accepted: August, 2013}

As immigrant contributions to the U.S. economy and society are debated, female migrants continue to increase their number in the U.S. work force. Little is known about the economic experiences of undocumented female Mexican migrants in the United States. Do women in traditional migrant destinations fare better than those in new destination cities, as has been shown for males? Does a strong social network positively impact earnings and participation in economic life? This study explores these questions with data collected at Mexican consulates in seven U.S. cities during 2004 and 2005 by Pew Hispanic Center field researchers. Controlling for education level and English fluency, social network and destination are examined for their effects on earnings and economic integration. The effects of social network on economic outcomes are also examined separately in new and traditional destinations. Evidence of the effect of education, English, social network, and destination on earnings and economic integration is consistent with previous findings for males, but nuances are found for this sample of female migrants that contributes to the literature. Experiences differ by destination with women in traditional migrant destination cities experiencing greater economic integration. Findings provide a rare glimpse into the economic experiences of undocumented female migrants in the U.S. Further research examining these factors after the recession and after increased deportations and anti-immigrant state and local ordinances is recommended.

Keywords: Undocumented Migrants / Mexican Females / Earnings / Economic Mainstream / New and Traditional Destinations 


\section{Introduction}

Continued immigration is vital to the health of the U.S. economy, but immigration laws have not kept up with current labor force needs (E. Goss, personal conversation, April 29, 2011). It is estimated that 8.3 million unauthorized immigrants participate in the U.S. labor force today (Passel \& Cohn, 2009). The largest group (59\%) is of Mexican origin (Passel \& Cohn, 2009). Scholars of immigration have turned much attention in recent years to the growth of Mexican migration in what is known as "new destination" states and cities (Massey, 2008). The well-being of these new migrants impacts these areas and largely depends on how well they do economically (Bean \& Stevens, 2003). Some research has shown that migrants earn less in new destination states than in traditional destination states (Leach \& Bean, 2006).

Among researchers who study work experiences of Mexican migrants, some have investigated the effect of migrants' legal status on earnings. As logic would predict, unauthorized status negatively affects earnings (Bean, Lowell \& Taylor, 1988; Koussoudji \& Cobb-Clark, 2002). Rivera-Batiz (1999) found that Mexican legal migrants earn, on average, $42 \%$ more than workers without legal authorization to work. Some researchers propose that lower wages are linked to lower educational achievement and less English proficiency (Livingston \& Kahn, 2002), often referred to as dimensions of human capital. Others argue that "legal status may affect their earnings independently of their personal and human capital characteristics" (Kossoudji \& Ranney, 1986, p. 850).

Another debated issue is whether unauthorized immigrants are joining the economic mainstream (Bean, Brown \& Rumbaut, 2006; Huntington, 2004). Gouveia, Carranza and Cogua, (2005) noted that lack of legal status often prevents immigrants from accessing credit cards, bank accounts, as well as other essentials such as driver's licenses and health insurance. Little is known yet about the effects of post-September 11 increased immigration enforcement actions. Sociologists propose these have heightened a sense of vulnerability and fear among newcomers (Gouveia, Carranza \& Cogua, 2005).

One element of migrant life thought to have a positive impact on economic participation is a strong social network. Social networks are thought to help migrants "overcome workplace vulnerabilities" (Amuedo-Dorantes \& Mundra, 2007, p. 849). A study by Amuedo-Dorantes and Mundra (2007) investigated the impact of social networks on the earnings of both legal and unauthorized Mexican migrant workers. They examined the impact of family networks and friendship networks and found that these networks are positively associated with increased earnings of both undocumented and documented Mexican migrants.

Most previous studies of Mexican immigrants investigate only the experiences of males, citing limited observations of women in their samples. Women, however, currently form a substantial proportion of the immigrant and Mexican origin labor force in the U.S. (Livingston $\&$ Kahn, 2002). One recent study was successful in obtaining participation from many Mexican migrant women. Between the years 2004 and 2005, the Pew Hispanic Research Center collected data from nearly 5,000 Mexican migrants in Mexican consulates throughout the United States. Forty-three 
percent of participants in the project, entitled 'Survey of Mexican Migrants', were women. Veteran demographer and senior research associate at the Pew Hispanic Center, Jeffrey S. Passel, stated that the sample from the 'Survey of Mexican Migrants' "demonstrates significant similarities with the estimated characteristics of the undocumented population" (Appendix 1, p. 22). The report calls this survey a "first-of-its-kind" (Pew Hispanic Center, 2005). This data allowed for the investigation of factors that influence the earnings and economic integration of largely unauthorized Mexican migrant women. It included items that could be used to further investigate questions of job earnings and assess economic integration. The Pew data was gathered in four traditional destination areas: Los Angeles, Fresno, Dallas, and Chicago, and three new destination areas: New York (new for Mexican migration), Atlanta, and Raleigh. This allowed for the exploration of the question of whether female Mexican migrants have a different economic experience in new versus traditional regions.

The current study analyses the data from the Pew Migrant Survey in a new way. It seeks to extend the findings of Amuedo-Dorantes and Mundra (2007) that social networks (as measured by number of relatives in the United States) are positively associated with earnings, testing to see if this is the case in this sample of undocumented female Mexican migrants. The focus of the present study is to investigate the effect of social networks on both earnings and economic integration controlling for level of education and English fluency of female Mexican migrants. How these associations differ for women who live in areas traditionally settled by Mexican migrants versus those more recently settled will also be explored. In other words, the objectives of this study are to test if earnings and economic integration are predicted by social network above and beyond education level and English fluency, and to examine how the associations are different in traditional and new destinations.

The primary analysis will consist of running two multiple regressions in two different groups together in one model (see Figure 1). The outcome variables, 'earnings' and 'economic integration', will be regressed on the two covariate predictors, 'education' and 'English'. The continuous independent variable, 'social network', will be added in a second regression. An additional direct logistic regression will be conducted to examine the associations with 'destination' added as an additional categorical variable. Finally, relationships will be compared in 'traditional' and 'new destinations'. 


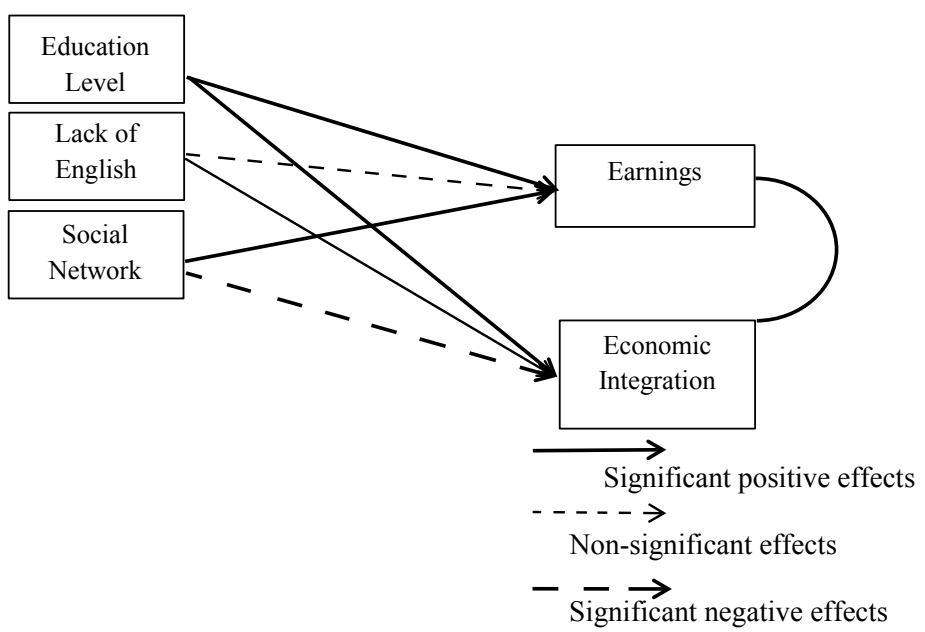

Figure 1. Predicted Associations between Variables in Traditional and New Destinations

\section{Method}

\subsection{Participants}

Participants in this study were 1,942 Mexican migrant women who were interviewed by researchers from the Pew Hispanic Center while they were applying for a matricula consular, an identity document issued by Mexican consulates in the United States. This data was taken from the 'Survey of Mexican Migrants' conducted by Pew Hispanic Center field staff in Los Angeles, New York, Chicago, Atlanta, Dallas, Raleigh, and Fresno, from July 12, 2004, to January 28, 2005. The Pew Center survey also included 2,894 male participants (57\% of respondents) as well, but they are not included in the analysis for this study. The average age of participants is 34 $(\mathrm{M}=33.63, \mathrm{SD}=15.00)$. The women, on an average, had 3 children $(\mathrm{M}=2.97, \mathrm{SD}=$ 1.70). More than half (61\%) of the participants began their present stay in the United States six years ago or more (39\% have been here five years or less). It is believed that participants are largely residing in the United States without authorization or means to obtain legal documents under current immigration statutes.

\subsection{Procedure}

Participants completed a 12-page survey consisting of 62 questions regarding demographic information, experiences in Mexico and the U.S., employment and financial information, medical care and social services information, and attitudes toward immigration programs. They were informed that participation was voluntary and that all of their responses would be kept anonymous and confidential. It was emphasized that reading and writing was not a prerequisite to participation. Potential participants were advised that their participation in the survey would not affect their 
dealings with the consulate. In addition, they were informed that upon completion of the survey, they would receive a long-distance phone card as a token of gratitude for their time and patience. Pew field researchers offered participants the choice of self-administering the survey or having an interviewer read the questions aloud and fill in the questionnaire for them (Pew Hispanic Center, 2005, Appendix 1, p.21).

\subsection{Measures}

- Education and English fluency. Covariate predictors in this study are 'education level' and 'English proficiency', taken from questions 5 and 6 in the 'Survey of Mexican Migrants'. The range of possible responses for education level included: 1, "Did not attend/complete school," 2, "K-11, Did not graduate high school," 3, "Secondary/Tech," 4, "High school grad or equivalent," and 5, "college or more." English proficiency was selfreported in answer to the question "How much English do you speak?". A 4-point scale of responses ranged from 1, "A lot," to 4, "None." Note that higher values indicate less ability to speak English.

- $\quad$ Social Network and Destination. Question 13 in the survey was selected as a measure of social network. The question reads, "How many relatives?" and corresponds to the previous question that asked "Do you have relatives, other than your children or your spouse, who live in the U.S.?" As extensive research discusses the differences in conditions for migrants in "traditional" and "new" destinations, the internal tracking code labeled "Market" in the 'Survey of Mexican Migrants' was selected for the measure of Destination. The variable was recoded from 7 discreet cities to two destinations and the new variable was labeled "Destination." Consistent with the literature, Los Angeles, Chicago, Fresno, and Dallas were considered as traditional destinations. New York, Atlanta, and Raleigh, were considered as new destinations for Mexican migrants.

- Earnings and Economic Integration. Question 39 from the 'Survey of Mexican Migrants' was selected as a measure of earnings. The question reads "About how much do you earn per week?" Possible responses range from 1, "\$1-100 per week" to 6, "More than $\$ 500$ per week." In order to investigate the empirical question raised in the literature regarding whether undocumented Mexican migrants participate in the mainstream of the economy, a composite outcome variable was created. Four items from the 'Survey of Mexican Migrants', (questions 45, 46, 58, and 60, regarding possession of a credit card, a bank account, a cell phone, and access to a computer or the internet when needed) were selected as variables related to participation in the U.S. economy. These were summed into a composite variable and labeled "Economic Integration." The values on the new variable range from zero, meaning possession of none of the items and no computer access, to 4 , meaning possession of a credit card, bank account, cell phone, and access to a computer. 


\section{Results}

As the focus of this study is the experience of female Mexican migrants, the data set was split by sex and a new data set of just females $(\mathrm{N}=1942)$ was retained for this analysis. Variables not of interest for this current study were eliminated from the analysis. Data were evaluated for accuracy of coding. Several items were re-coded: a) to correct the specification of the code for Earnings, b) to create consistency of coding for creating the Economic Integration composite, and c) to create a categorical variable (Destination) from seven discreet responses. After standardizing the variables, the distribution of z-scores was examined for outliers. Twenty-six outliers in the Social Network variable were considered to be plausible answers (some have no relatives and some have many extended family members in the U.S.) and kept in the analysis. Outliers were not found in the other variables. Missing data were believed to be random. Frequencies, histograms, means, standard deviations, and correlations were obtained for all variables included in this analysis. Table 1 presents means, standard deviations, minimum and maximum responses, and valid responses for each measure. Correlations between all of the variables are reported in Table 2. No variables appeared to be redundant or caused concern for multicollinearity. It made sense that the correlation between the two outcome variables would be positively correlated, but the fact that the correlation is not large tells us they are tapping into different aspects. When the histograms were examined for normality and for sufficient variance, the Social Network measure was found to be positively skewed. Most responses $(\mathrm{N}=955,67 \%)$ were less than the mean of 14 relatives, but nearly 300 women reported extended family networks between 20 and 40, with 78 reporting between 50 and 90 , and 10 reporting 95 or more.

Table 1. Descriptive Statistics for Measures of Interest

\begin{tabular}{lccccc}
\hline Measure & Mean & SD & Minimum & Maximum & N \\
\hline $\begin{array}{l}\text { Education } \\
\text { Level }\end{array}$ & 2.96 & 1.04 & 0 & 5 & 1,942 \\
$\begin{array}{l}\text { English } \\
\text { fluency }\end{array}$ & 2.68 & 1.00 & 1 & 4 & 1,918 \\
$\begin{array}{l}\text { Social } \\
\text { Network }\end{array}$ & 13.68 & 15.33 & 0 & 96 & 1,426 \\
$\begin{array}{l}\text { Earnings } \\
\text { Economic }\end{array}$ & 2.96 & 1.20 & 1 & 6 & 1,315 \\
Integ. & 1.53 & 1.24 & 0 & 4 & 1,635 \\
\hline
\end{tabular}


Table 2. Correlations between Measures

\begin{tabular}{lcccccc}
\hline & Educ & English & Social Net & Destination & Earnings & EconInt \\
\hline Education & - & & & & & \\
Level & & & & & & \\
English &. .41 & - & & & & \\
fluency & & & & & & \\
Social & .03 &. $.15^{*}$ & - & & & \\
Network & & & & & & \\
Destination &. .02 & $.06^{*}$ & $-.16^{*}$ & - & & \\
Earnings & .05 & $-.17^{*}$ & $.10^{*}$ & -.02 & - & \\
Economic & $.20^{*}$ & $-.39^{*}$ & $.26^{*}$ & $-.14^{*}$ & $.35^{*}$ & - \\
Integ. & & & & & & \\
Note. ${ }^{*} \mathrm{p}<.05$ & & & & &
\end{tabular}

The analyses conducted included two multiple regressions in two different groups in one model. This was possible through structural equation modeling using the computer software MPlus (Version 6.1, Muthen \& Muthen, Los Angeles, CA). The first step was to control for the two covariates: Education level and English fluency. In model 1 (see Figure 2), the two dependent variables, 'Earnings' and 'Economic Integration', were regressed on the two covariate predictors, 'Education' and 'English fluency'. Earnings were found to be positively predicted by Education $(B=0.10, \beta=.08$, S.E. $=.03, z=2.92, p<.05)$. Earnings were found to be significantly negatively predicted by lack of English fluency $(B=-.24, \beta=-.20$, S.E. $=.03, z=-6.87$, $p<.05)$. Economic Integration was not predicted by Education but was significantly negatively predicted by lack of English fluency $(B=-0.46, \beta=-.37$, S.E. $=.02, z$ $=-16.33, p<.05)$. Six percent of the variability in Earnings is explained by both covariates together and $15 \%$ of the variability in Economic Integration is explained by the two covariates Education and English fluency together.

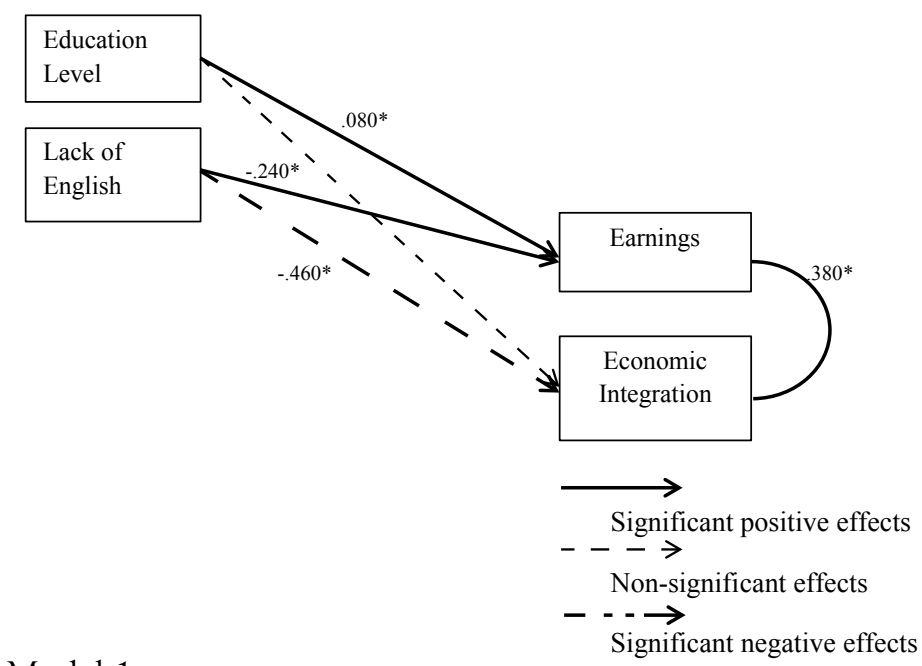

Figure 2. Model 1 
In the second model (see Figure 3), Social Network was added as a predictor and regressed on the two DVs: Earnings and Economic Integration. Larger Social Networks were found to predict higher Earnings $(B=.004, \beta=.003$, S.E. $=.002, z(1$ tailed $)=1.66, p<.05)$ and also greater Economic Integration $(B=.015, \beta=0.012$, S.E. $=.002, z=7.30, p<.05)$. Social Network predicted $7.4 \%$ of Earnings and $20.0 \%$ of Economic Integration.

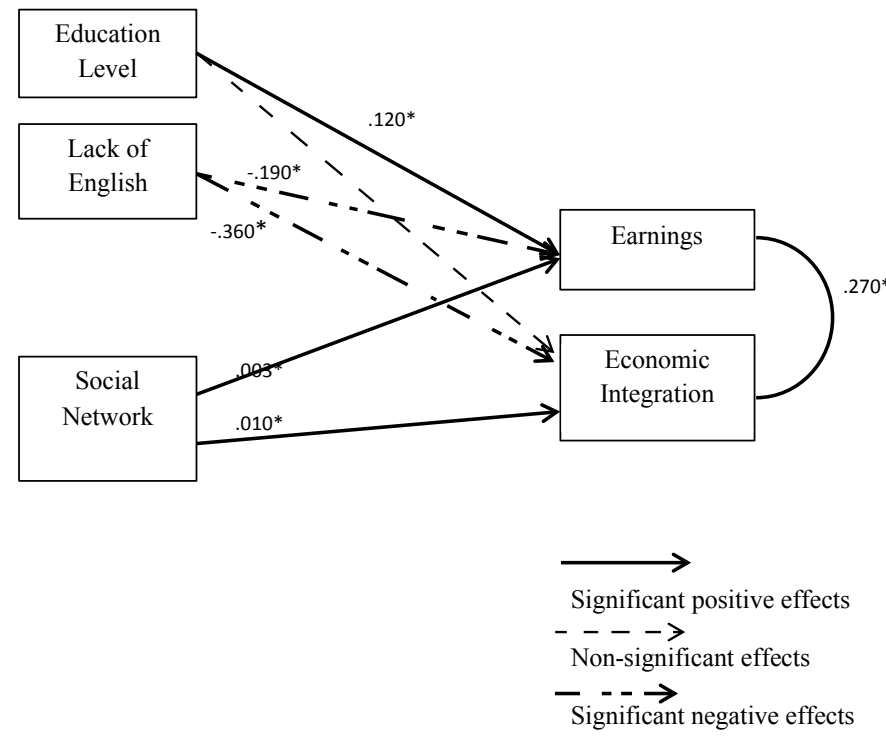

Figure 3. Model 2

To examine if the addition of the Social Network variable explains significantly more variance than the two covariate predictors Education and English, the R-square change was obtained. For Earnings the difference between models was not significant $\left(\Delta R^{2}=.014\right.$, S.E. $\left.=.016, p>.05\right)$. This indicates that though the Social Network variable is a significant predictor, its effect is weak on earnings. It does not significantly increase prediction above and beyond the covariates. The R-square change for Economic Integration between models was significant, $\left(\Delta R^{2}=.049\right.$, S.E. $=.02, p<.05)$ indicating that Social Network accounts for significant variance in Economic Integration above and beyond Education and English.

To examine if female migrants in Traditional Destinations have significantly higher Economic Integration than female migrants in New Destinations, a logistic regression was conducted with the variable Destination (Traditional and New) added as a categorical predictor. The results indicate that Destination had no effect on Earnings, but did negatively predict Economic Integration $(B=-.25$, S.E. $=.08$, $z=-3.02, p<.05)$. Traditional Destinations were coded 1 and New Destinations were coded 2, so this finding can be interpreted that female Mexican migrants demonstrate no difference in earnings in Traditional and New Destinations, but have significantly higher Economic Integration in Traditional Destinations.

Finally, to examine the differing effects of the covariates and Social Network on the dependent variables in Traditional and New Destinations, a multi-group 
comparison model was tested in SEM. Results are presented in Figure 4. In Traditional Destinations, Education impacted Earnings $(B=.16, \beta=.13$, S.E. $=$ $.04, z=3.59, p<.05)$, but not Economic Integration. Lack of English fluency negatively impacted both Earnings $(B=-.20, \beta=-.16$, S.E. $=.04, z=-4.29, p<.05)$ and Economic Integration $(B=-.46, \beta=-.36$, S.E. $=.03, z=-11.92, p<.05)$. Social Networks did not impact Earnings, but did positively impact Economic Integration $(B=.01, \beta=0.01$, S.E. $=.002, z=6.17, p<.05)$. In the Traditional Destinations, Social Network explains $7 \%$ of the variance in Earnings and $15 \%$ of the variance in Economic Integration.

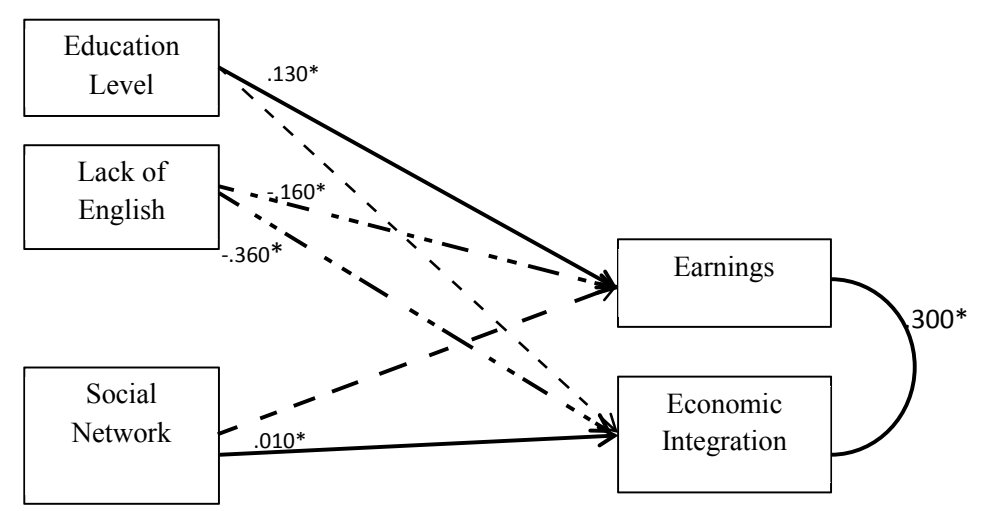

Associations in Traditional Destinations

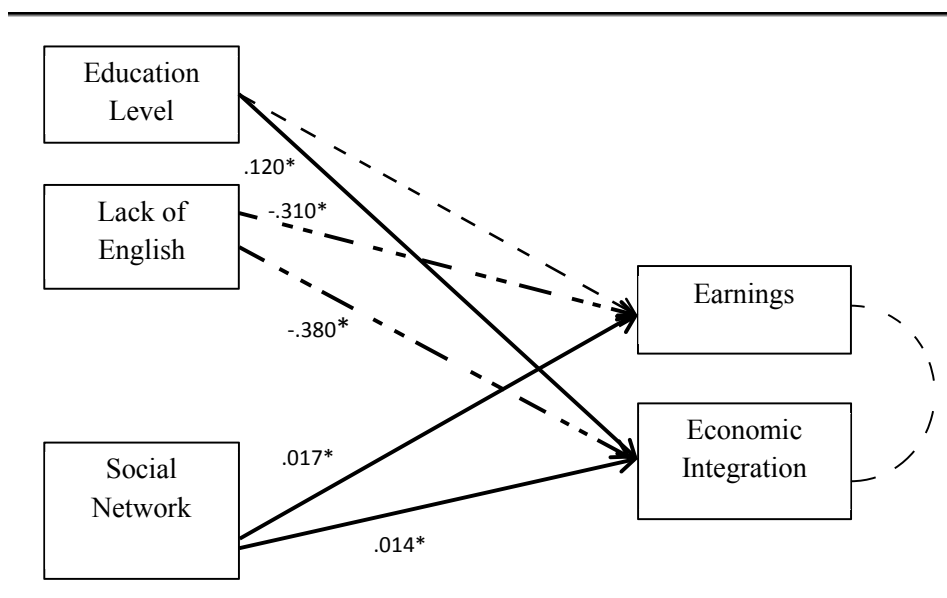

Associations in New Destinations

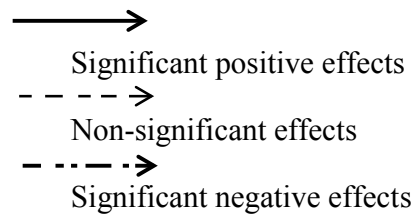

Figure 4. Model 3 
In New Destinations, Education did not impact Earnings, but did impact Economic Integration $[B=.12, \beta=.12$, S.E. $=.07, z=1.71$ (1 tailed), $p<.05]$. Lack of English fluency negatively impacted both Earnings $(B=. .33, \beta=. .31$, S.E. $=.08$, $z=-4.00, p<.05)$ and Economic Integration $(B=-.39, \beta=-.38, S . E .=.06, z=-6.07$, $p<.05)$ as in Traditional Destinations. Social Networks positively impacted both Earnings $(B=.02, \beta=.02$, S.E. $=.01, z=2.33, p<.05)$ and Economic Integration $(B$ $=.01, \beta=.01$, S.E. $=.01, z=2.28, p<.05)$. In the New Destinations, Social Network explains $13 \%$ of the variance in Earnings and $19 \%$ of the variance in Economic Integration.

\section{Discussion}

The value of the data from this unique sample gathered by field researchers from the Pew Hispanic Center with the cooperation of the Mexican government is difficult to overstate. The range of questions, the size of the sample, and the participation of so many working Mexican migrant females in 2004 and 2005 allowed for this study's exploration of factors associated with the economic experiences of these largely undocumented Latinas in traditional and new regions of the U.S.

Small but substantive variability in earnings and economic integration were explained by the human capital factors of education level and English proficiency. This supports research that claims that more education and English are associated with greater earnings. The finding that education and English contribute to greater mainstream economic participation (as measured by possession of a bank account, credit card, cell phone, and computer access) of undocumented Mexican migrant women is a contribution to the literature. These effects were somewhat different for women in traditional and new destination cities. English fluency was important for both earnings and economic integration in both traditional and new regions. Education was important for earnings, but not for economic integration in traditional migration cities.

Social networks were found to positively impact earnings and economic integration for undocumented Mexican migrant working women. Small but substantive variability in earnings and economic integration can be explained by social network for this group. Social network does not explain significantly more variance in earnings above that of education level and English proficiency together. A larger social network accounts for variance in mainstream economic participation beyond the effect of education and English. In traditional destinations, social network positively impacted economic integration, but not earnings. Social network explained slightly more of the variance in economic integration (19\% vs 15\%) and of earnings (13\% vs $7 \%$ ) in new as compared to traditional destination cities. Female Mexican migrant workers were found to have significantly higher economic integration in traditional destination cities. This merits further study as it is not accounted for in the literature. 


\section{Practical Implications}

The findings support the importance of the availability of English classes if women are to further their well-being and economic contributions. Research reveals that women desire to learn English, but often are not able to find available classes and access to adequate child care. Questions remain regarding the role of education in benefiting Mexican migrant women's economic integration.

\section{Limitations and Further Research}

Limitations of this study include that the data were collected with the single method of self-report surveys. The English fluency question (\#6) could have been re-coded for ease of interpretation (so larger numbers would mean higher fluency). Exploratory factor analysis with the larger Pew data set might reveal other factors of interest and import that should be considered in a parsimonious but illuminating model to investigate variables that impact female migrants' earnings and economic integration. Research indicates that a third important human capital variable that influences wages (in addition to education and English proficiency) is U.S. work experience (Livingston \& Kahn, 2002). For future model specification, this could be included as an additional covariate.

It would also be interesting to see if the results obtained here would be different after the economic crisis of 2008-2009 and in states and cities that have passed anti-immigrant ordinances. The deportation of 400,000 undocumented immigrants during the past three years may have affected the strength of the social networks of migrant women. How do the associations explored in the current study differ between Mexican migrant men and women? These would all be fruitful directions for further research. Though small, the effects of these analyses provide a beginning understanding of factors that influence the economic lives of this rarely viewed population of working women.

\section{Acknowledgements}

I wish to thank the Pew Hispanic Center for making available the data base utilized in this study and Dr. Jonathan Santo for his assistance with the statistical analyses.

\section{References}

Amuedo-Dorantes, C. \& Mundra, K. (2007). Social networks and their impact on the earnings of Mexican migrants. Demography, 44, 849-863.

Bean, F. D., Lowell, L. B. \& Taylor, J. L. (1988). Undocumented Mexican immigrants and the earnings of other workers in the United States. Demography, 25, 35-52.

Bean, F. D., Brown, S. K. \& Rumbaut, R. (2006). Mexican Immigrant Political and Economic Incorporation. Perspectives on Politics, 4, 309-313.

Bean, F. \& Stevens, G. (2003). America's newcomers and the dynamics of diversity. New York: Russell Sage Foundation. 
Huntington, S. P. (2004). Who Are We? The Challenges to America's National Identity. New York: Simon \& Schuster.

Gouveia, L, Carranza, M. A. \& Cogua, J. (2005). The Great Plains migration: Mexicanos and Latinos in Nebraska. In V. Zúniga \& R. Hernández-León (Eds.). New Destinations: Mexican Immigration in the United States. (pp. 23-49). New York: Russell Sage Foundation.

Koussoudji, S. \& Cobb-Clark, D. A. (2002). Coming out of the shadows: Learning about legal status and wages from the legalized population. Journal of Labor Economics, 20, 598-628.

Kossoudji, S. \& Ranney, S. I. (1986). Wage rates of temporary Mexican migrants to the U.S.: The role of legal status. Unpublished discussion paper. Population Studies Center, University of Michigan, Ann Arbor.

Leach, M. A. \& Bean, F. D. (2006). Mexican-born persons' earnings and settlement in new destinations: A decomposition analysis. Extended Abstract Submission. Center for Research on Immigration, Population, and Public Policy. University of California, Irvine.

Livingston, G. \& Kahn, J. R. (2002). An American dream unfulfilled: The limited mobility of Mexican Americans. Social Science Quarterly, 83, 1003-1012.

Massey, D. S. (2008). New faces in new places: The changing geography of American Immigration. New York, NY: Russell Sage Foundation.

Passel, J. \& Cohn, D. (2009). A Portrait of unauthorized immigrants in the United States. Accessed on April 5, 2012: http://www.pewhispanic.org/2009/04/14/ a-portrait-of-unauthorized-immigrants-in-the-united-states/

Pew Hispanic Center. (2005). Survey of Mexican migrants. Washington D. C.: Pew Research Center. Accessed on January 29, 2012: http://www.pewhispanic. org/2005/03/02/survey-of-mexican-migrants-part-one/

Rivera-Batiz, F. (1999). Undocumented workers in the labor market: An analysis of the earnings of legal and illegal Mexican immigrants in the United States. Journal of Population Economics, 12, 91-116. 